Journal of Biotechnology and Strategic Health Research

\author{
Derleme / Review
}

http://dergipark.org.tr/tr/pub/bshr

\title{
Bağırsak Mikrobiyotası ve Toll Benzeri Reseptörler Arasındaki İlişki: Bağışıklık ve Metabolizma
}

\author{
The Relationship Between Intestinal Microbiota and Toll-Like Receptors: \\ Immunity and Metabolism
}

\section{Selen Güçliü Durgun', (iD $₫$ Asuman Deveci Özkan²}

${ }^{1}$ Tibbi Biyoloji Anabilim Dalı, Tip Fakültesi, Lokman Hekim Üniversitesi, Ankara

${ }^{2}$ Tibbi Biyoloji Anabilim Dalı, Tip Fakültesi, Sakarya Üniversitesi, Sakarya

ORCID ID: Selen Güçlü Durgun, https://orcid.org/0000-0003-3002-3919, Asuman Deveci Ozkan https://orcid.org/0000-0002-3248-4279

^Sorumlu Yazar / Corresponding Author: Asuman Deveci Özkan, e-posta / e-mail: deveci@sakarya.edu.tr

Geliş Tarihi / Received : 26-03-2021 Kabul Tarihi / Accepted: 06-04-2021 Yayın Tarihi / Online Published: 30-04-2021

Güçlü Durgun S., Özkan Deveci A. Bağırsak Mikrobiyotası ve Toll Benzeri Reseptörler Arasındaki İlişki: Bağışıklık ve Metabolizma,

J Biotechnol and Strategic Health Res. 2021;5(1):12-21

$\ddot{O} z$

İntestinal kanal, mikrobiyota ile simbiyotik bir ilişkinin oluşmasına izin veren ve mikroorganizmaların invazyonunu kısıtlayan çeşitli stratejiler geliştirmiştir. Toll benzeri reseptörler (TLR), makrofajlar, dendritik hücreler (DC'ler), T lenfositler ve bağırsak epitel hücreleri dahil olmak üzere çeşitli hücre tiplerinde ifade edilen reseptörlerdir. Patojenlere özgü ve hayatta kalmaları için gerekli olan patojen ilişkili moleküler modelleri (MAMP) tanıyan patojen tanıma reseptörleri (PRR'ler) olarak görev yapmaktadırlar. İnsanda bağırsak mikrobiyotası ile bağırsak epitel hücreleri ve bağışılık hücreleri üzerindeki TLR'ler arasındaki etkileşimler, bağışıklık sisteminin homeostazının korunmasına destek olmaktadırlar. TLR ilişkili yolaklar enerjiyi bağışılık yanııına ayırmak için bağışıklık hücrelerindeki içsel metabolizmayı düzenlemektedir. TLR2 aktivasyonu ile anti-inflamatuar yanıt sonrası kommensal bakteriler "patojenik olmayan" olarak tanınmaktadır. TLR4 gen ifadesi, obez veya tip 2 diyabet hastalarının adipoz doku, periferik kan veya kas dokusu örneklerinde ve obez farelerin adipoz dokularında artmakta ve insülin direnci ile ilişkili olmaktadır. TLR5 yoksun farelerin mikrobiyota kompozisyonlarındaki değişikliklerle ilişkili olan insülin direnci ve artan adipozite dahil olmak üzere metabolik sendrom geliştirmeye eğilimli oldukları bildirilmiştir. Ayrıca TLR antagonistlerinin kullanımı ile immünosupresyonun sağladığı faydalı etkiler metabolik ve kardiyovasküler hastalıklar için araştırılmaya devam etmektedir. Genetik ve çevre etkisiyle bağırsak mikrobiyotasındaki değişiklikler, sorunlu konak bağışıllık tepkisine neden olabilmekte ve mikrobiyota manipülasyonları ile hastalarda mikrobiyotanın yeniden programlanması erişilebilir ve ümit verici tedavi şekilleri sunabilmektedir. Bu nedenle, mikrobiyota ve bağı̧ııklık sistemi arasındaki ilişkinin metabolik parametreleri nasıl düzenleyeceğini anlamak, metabolik hastalıkların tedavisinde ilerlemeler sağlayabilecektir.

Anahtar Bağırsak mikrobiyotası, TLR, metabolizma,bağısııklık

Kelimeler

$\ddot{O} z$

The intestinal tract has developed various strategies that allow a symbiotic relationship with the microbiota and restrict the invasion of microorganisms. Toll-like receptors (TLRs) are expressed in a variety of cell types, including macrophages, dendritic cells (DCS), T lymphocytes, and intestinal epithelial cells. TLRs act as pathogen recognition receptors (PRRs) that recognize pathogen-associated molecular patterns (MAMP) specific to pathogens and essential for their survival. Interactions between intestinal microbiota in humans and TLRs on intestinal epithelial cells and immune cells support the maintenance of the homeostasis of the immune system. TLR-related pathways regulate intrinsic metabolism in immune cells to allocate energy to immune response. Commensal bacteria are recognized as "non-pathogenic" after anti-inflammatory response with TLR2 activation. TLR4 expression is increased in adipose tissue, peripheral blood or muscle tissue samples of obese or type 2 diabetes patients and in adipose tissues of obese mice and is associated with insulin resistance. TLR5-deficient mice have been reported to be prone to developing the metabolic syndrome including insulin resistance and increased adiposity, which is associated with changes in microbiota composition. In addition, the beneficial effects of immunosuppression with the use of TLR antagonists continue to be investigated for metabolic and cardiovascular diseases. The intestinal microbiota changes due to genetics and environmental influences can cause host immune response problems and certain microbiota manipulations and reprogramming of microbiota in patients can offer accessible and promising treatment options. Therefore, it is important to understand how the relationship between the microbiota and the immune system will regulate metabolic parameters which could lead to advances in the treatment of metabolic diseases.

Keywords Intestinal microbiota, TLR, metabolism, immunity 


\section{GIIRIŞ}

Gastrointestinal kanal insanda bakteri, fungus ve virüsler gibi farklı mikrobiyal popülasyonların kolonilerinden oluşmaktadır. ${ }^{1}$ Bakteriler, 500-1000 farklı tür ile mikrobiyotadaki en büyük popülasyona sahip grubu oluşturmaktadır. ${ }^{1,2}$ Bu çeşitliliğin neden olduğu antijenik yük, konak ile bakteri arasındaki simbiyotik ilişki ve istilacı enterik patojenlere karşı koruyucu inflamatuar yanıt sağlayabilen bağırsak tarafından tolere edilmektedir.

Intestinal kanal, mikrobiyota ile simbiyotik bir ilişkinin oluşmasına izin veren ve mikroorganizmaların bağırsak epitel bariyeri yoluyla invazyonunu kısıtlayan çeşitli stratejiler geliştirmiştir. Bu simbiyotik ilişki, bağırsaktaki zararlı bakteri sayısının minimumda kalmasını sağlamaktadır. Kommensal mikrobiyota üyeleri ise patojenlerle mücadele ederek, bağırsaktaki kolonizasyonlarını sınırlandırmaktadır. ${ }^{3}$ Buna ek olarak, Goblet hücrelerinden salgılanan musin glikoproteinleri, kalın bir mukus tabaka oluşturarak bakteri florası ile bağırsak epitel hücrelerini birbirinden ayıran fiziksel bir bariyer oluşturmaktadır. ${ }^{4}$ Mukoza hücreleri tarafından salgılanan birçok antibakteriyel faktör doğrudan mikrobiyotanın gelişimini düzenlemektedir.

Salgılanan immunoglobulin A'lar (IgA), intestinal mikroorganizmalara bağlanmakta ve epitel hücre tabakalarından invazyonlarını önleyerek kommensal bakterileri kontrol etmektedir. Antijene özgü IgA havuzu, ${ }^{5}$ Peyer plaklarından göç eden plazma hücreleri ya da epitelyal sinyallere cevap veren diğer mukoza-ilişkili lenfoid dokular tarafından üretilmektedir. Sağlıklı insan bağırsağında, mikrobiyal yükün düzenlenmesi ile sabit bir homeostaz sağlanmakta ve dengenin bozulması bağırsaklarda çeşitli patolojik durumlara neden olmaktadır. Bağırsak florasının patolojik bakterilerle homeostazının değişmesi "disbiyoz" adı verilen duruma neden olmaktadır. Bağırsak disbiyozu, normalde vitamin salgılayan, sindirime destek olan, bağırsak bariyerinin geçirgenliğini düzenleyen, enfeksiyonlardan koruyan ve patojenlerin çoğalmasını önleyen normal bakteri florasındaki değişiklik ile karakterize olan patolojik bir durumdur. ${ }^{6}$
Sonuç olarak, homeostazın disbiyoz veya immün yanıtların düzensizliği ile bozulması, inflamatuar bağırsak hastalıklarına (IBD) duyarlılığı arttırabilmektedir.?

Toll benzeri reseptörler (TLR), makrofajlar, dendritik hücreler (DC’ler), T lenfositler, kanser ve bağırsak epitel hücreleri dahil olmak üzere çeşitli hücre tiplerinde ifade edilen tip I transmembran reseptörlerdir ve ligandları ile uyarılmsı ile aşağı yönlü bir sinyal iletimi başlatılarak bağışıklık sistemi ile ilgili genlerin ifadesini arttırmaktadırlar. ${ }^{8}$ Patojenlere özgü ve hayatta kalmaları için gerekli olan patojen ilişkili moleküler modelleri (MAMP) tanıyan patojen tanıma reseptörleri (PRR'ler) olarak görev yapmaktadırlar. ${ }^{9}$ İnsanda bağırsak mikrobiyotası ile bağırsak epitel hücreleri ve bağışıklık hücreleri üzerindeki TLR'ler arasındaki etkileşimler, bağışıklık sisteminin homeostazının korunmasina destek olurken hepatositler ve adipositlerde de ifade edilmektedirler. ${ }^{10}$ TLR'lerin etkinlikleri inflamatuar moleküller üretebilmelerine rağmen, karaciğer ve yağ dokusunda bulunan bağışıklık hücrelerine kıyasla düşük kalmakta ve bu hücrelerdeki TLR'lerin işlevini zorlaştırmaktadır. ${ }^{11}$ TLR aktivasyonunun aracilık ettiği inflamasyon, yağ dokusu ve karaciğerdeki metabolizma ile ilgili genlerin ifadesinin azalmasına yol açmaktadır. ${ }^{12}$ Düşük dereceli inflamasyon, artan bağırsak geçirgenliğine bağlı olarak obezite ve metabolik hastalıklarda sıklıkla görülmekte ve muhtemelen bağırsak mikrobiyotası tarafından üretilen moleküller periferik TLR'leri aktive etmektedir. ${ }^{13}$ TLR ilişkili yolaklar enerjiyi bağışıklık yanıtına ayırmak için bağışıklık hücrelerindeki içsel metabolizmayı düzenlemektedir. Bu tür bir enerji yer değiştirmesinin hücreler arası seviyede mi yoksa organlar arası seviyede mi gerçekleştiği bilinmemektedir. Doğuştan gelen ve adaptif bağışıklıkta TLR’lerin işlevi ve TLR'lerin bağırsak mikrobiyotası ile etkileşim yoluyla konakçı bağışıklığını nasıl düzenlediği araştırma konuları arasında ilgi çekici olarak yer almaktadır.

Bu kapsamda bu derlemenin amacı, doğuştan gelen bağ 1 şıklık sistemi hücrelerinin önemli bir bileşeni olan TLR'lerin bağırsak mikrobiyotası ile etkileşiminin bağışıklık ve 
metabolizma anlamında ele alınarak, TLR aktivasyonunun konakçı bağışıklığı üzerindeki rolünün metabolizma ile ilişkisinin ve mikrobiyota profili ile TLR’ler arasındaki bağlantının incelenerek literatüre bu konuda katkı sağlanmasidir.

\section{Toll-Benzeri Reseptörler (TLR'ler)}

TLR'ler, 1985 yılında Drosophila'da tanımlanan Toll geni tarafından kodlanan proteine olan benzerliklerinden dolayı bu adı almışlardır. İnsanlarda toplam 10 adet TLR ifade edilirken; her TLR, belirli sinyal yolunun aktivasyonuna yol açan farklı MAMP'lere yanıt vermektedir. Yapısal olarak ise TLR'ler, hücre dışı bir adet lösin açısından zengin tekrar alanı (LRR) ve bir adet hücre içi Toll/IL-1 reseptörü (TIR) alanının varlığ LRR'ler çok sayıda proteinde bulunmakta ve ligand tanıma ve sinyal iletiminde rol oynamaktadırlar. ${ }^{15}$ TLR'nin TIR alanı, hücre içi sinyalleşme ve aktivasyon için gereklidir ve bu alan, TLR ailesine dahil olan reseptörler arasında değişen derecelerde dizi benzerliğine sahip olan yaklaşık 200 amino asit içermektedir. Bunun yanı sıra, TIR alanlarının üç alt grubu bulunmaktadır. Bu alt gruplardan birincisi, alt grup l'in proteinleri, makrofaj monositleri tarafından üretilen interlökinler tarafından kullanılan reseptörlerdir ve DC’lerin tümü, hücre dışı İmmünoglobulin (Ig) alanlarına sahiptir. Alt grup 2'nin proteinleri, klasik bir TLR tipi olarak kabul edilmekte ve doğrudan veya dolaylı olarak mikrobiyal moleküllere bağlanmaktadır. Son olarak alt grup 3'ün proteinleri, alt grup 1 ve 2'nin proteinlerinden gelen sinyallere aracılık eden TLR'lerin üreme hücrelerinde kodlanan tip I transmembran reseptörlerinin sitosolik adaptör proteinleri olarak görev yapmaktadır. ${ }^{15}$

TLR'lerin ligandları tarafından aktivasyonu, birkaç dendritik hücre (DC), T lenfositini ve bağırsak epitelyal hücre içi sinyal yolaklarını indüklemektedir ve indüklenen sinyal yolları aracılığıyla sitokinlerin ve kemokinlerin sentezi ve enfeksiyonun kontrolü için önemli olan diğer genlerin transkripsiyonunun başlamasını sağlamaktadır. TLR'lerin ligandları tarafından aktivasyonu ile başlayan iki ana sin- yal yolu bulunmaktadır. Çoğu TLR tarafından aktive edilen ana ve birinci yol, transkripsiyon faktörü NF-Kß'nin ve mitojenle aktive olan protein (MAP) kinazlar, p38 ve JNK'nın aktivasyonuna yol açmaktadır. Bu sinyal yolağı ile birçok proinflamatuar genin ekspresyonunu artmaktadır. İkinci yol sadece TLR3 ve TLR4'ün ligandları tarafından uyarılmasıyla aktive edilmektedir ve hem NF-Kß hem de bir transkripsiyon faktörü olan interferon düzenleyici faktör 3'ün (IRF3) aktivasyonuna yol açmakta ve interferon-beta gibi antiviral genlerin ekspresyonunu başlatmaktadır. ${ }^{15}$ TLR sinyal yolaklarında merkezi ve en önemli role sahip olan adaptör proteinler; MyD88, MAL (TIRAP olarak da bilinir), TRIF (TICAM1 olarak da bilinir) ve TRAM'dır (TICAM2 veya TIRP olarak da bilinir). MyD88 adaptör proteini TLR3 dışındaki tüm TLR'ler tarafından kullanılmaktadır. MyD88, MAP3 kinazların aktivasyonuna yol açan IRAK'ları (IL-1R ile ilişkili kinaz ailesi) uyararak sinyalin aşağı yönlü iletimini sağlamaktadır. MAP3 kinazlarından ikisi MEKK3 ve TAK1 olarak tanımlanmıştır ve bunlar NF-KB, MAP kinazlar, p38 ve JNK'yi aktive etmektedir ${ }^{15}$. MyD88-yoksun fareler üzerine yapılan çalışmalar, TLR’ler aracılığıyla sinyal iletiminin bağırsak homeostazında önemli bir rol oynadığını göstermektedir. Bu sinyal, antimikrobiyal ürünlerin mikrobiyal tanıma indüksiyonundan ve adaptif immün yanıtın modülasyonundan sorumlu tutulmaktadır. Ayrıca, MyD88'e bağımlı bir kommensal mikrobiyotanın tanınmasının epitel hücre homeostazı, yaralanma yanıtı ve antimikrobiyal peptidlerin indüksiyonu için gerekli olduğu gösterilmiştir. ${ }^{16}$

\section{Hücrelerde TLR Yolu İlişkili Metabolik Düzenlenme}

Glikolizin, makrofaj polarizasyonunda ve dendritik hücre aktivasyonunda çok önemli bir rol oynadığı iyi bilinmektedir. Dinlenme durumunda, dendritik hücreler $\beta$-oksidasyon ve oksidatif fosforilasyon yoluyla enerji kaynağı olarak lipitleri kullanmaktadırlar ${ }^{11}$. TLR'nin ligandı ile bağlanmas1, PI3K/Akt yolunu aktive etmekte ve ATP üretmek için glikolize doğru metabolik bir değişime yol açmaktadır. ${ }^{17}$ TLR’nin ligandına bağlanması üzerine aşağı yönlü kinazlar olan TBK1 ve IKKy'nin aktivasyonu, Akt'nin fosforilasyo- 
nunu indüklemekte ve Akt'nin aktivasyonu, mitokondrideki glikolizde heksokinaz-II için hız sınırlayıcı enzimin zenginleşmesini tetikleyerek aktivitesini arttırmaktadır. ${ }^{18}$ M1 makrofaj polarizasyonu sirasında, 6-fosfofrukto-2-kinaz / fruktoz-2,6-bifosfatazın (PFK2) karaciğer tipinden (L-PFK2) daha aktif ve her yerde bulunan bir tipine (u-PFK2) dönüşümü TLR (TLR2, 3, 4 ve 9) sinyal yolunun aktivasyonuna bağlı olmaktadır. ${ }^{19}$ Bunun tam tersine helmint enfeksiyonunda makrofajın M2 polarizasyonu s1rasında, MAPK kaskadının TLR2 ve TLR4'e bağlı aktivasyonu ve CREB, IL-10 üretimine ve akonitaz ve ADP'ye bağımlı glukokinaz dahil olmak üzere bir dizi metabolizma ile ilişkili genin eş zamanlı değişimine yol açmaktadır. ${ }^{20}$

Viral ve bakteriyel enfeksiyonlarda TLR3 ve TLR4'ün aktivasyonu, makrofajlarda kolesterol akışını düzenleyen karaciğer X reseptörüne (LXR) bağımlı genlerin ifadelenmesini baskılamaktadır. Tutulan kolesterol, makrofajların fagositik süreci için bir rezerv görevi görmekte, ancak ateroskleroz durumunda "köpük hücre" oluşumunu desteklemektedir. ${ }^{21}$ Viral enfeksiyonlara yanıt olarak aşağı yönlü akışta etkili ve önemli bir çekirdek faktörü olan IRF3'ün TLR3 sinyali ile aktivasyonu, bir yandan interferon üretimi yoluyla antiviral yanıtı uyarmakta ve diğer yandan retinoid $\mathrm{X}$ reseptörü-a'yı (RXRa) aşağı doğru düzenleyerek metabolik yanıtı baskılamaktadır. ${ }^{22}$ RXRa, metabolizma ile ilgili genleri düzenleyen bir nükleer ağ oluşturan peroksizom proliferatör ile aktive edilmiş reseptör- $\gamma$ (PPARy), LXR ve farnesoid X reseptörü (FXR) dahil olmak üzere diğer nükleer faktörlerle birlikte heterodimer oluşturmaktadır. ${ }^{23} \mathrm{Vi}$ rüsler kendi replikasyonlarını kolaylaştırmak için konakçının lipitlerini kullanabildiğinden, bu tür bir baskılama viral birleşmeyi önlemek için anahtar rol oynamaktadır. ${ }^{24}$ Hepatit B virüsü taşıyan transgenik farelerde TLR3, TLR4, TLR5, TLR7 veya TLR9 ligandının enjeksiyonunun viral replikasyonu inhibe ettiği gösterilmiştir. ${ }^{25}$ Bununla birlikte, depolamayı inhibe eden ve enerji harcamasını arttıran akut yanıtın aksine, makrofajlarda LPS'nin subenfeksiyöz dozu ile TLR4'ün kronik aktivasyonu, lipoliz ve $\beta$-oksidasyonda paralel bir azalma ile trigliserit formunda yağ asidi alımını ve depolanmasını kolaylaştırmaktadır. ${ }^{26}$ Trigliseritlerin uyarılmış alımı ve depolanması, obezite sırasında yağ dokusu makrofajlarında da gözlenmekte ve lipit birikimi, lipozomal biyogenez ile ilgili olmaktadır. Ancak, düşük dereceli inflamasyon devam ettiğinde glikolizden lipit depolamaya geçişin nedeni ve bunun fizyolojik ve/ veya patofizyolojik bir fenotip olup olmadığı belirsizliğini sürdürmektedir. Bu durum muhtemelen inflamatuar veya antimikrobiyal tepkileri sürdürmek, bakterilerin büyümeleri için piruvat ve asetil-CoA kullanmasını önlemek ve böylece büyümelerini sınırlamak için harici bir enerji kaynağı elde etmek için uyarlanabilir bir mekanizma olarak kullanılmaktadır. ${ }^{27}$

\section{Hücrelerde TLR Yolu ile Mikrobiyal Ürün Duyarlılığı}

Bağışıklık sisteminin görevlerinden biri, bir mikroorganizmanın kommensal mi yoksa istilacı ve potansiyel olarak patojen mi olduğuna karar vermektir. Bu nedenle öncelikle doğuştan gelen bağışıklık sistemi, her iki tür yabanciyı da "kendine-ait" ya da "kendine-ait olmayan" kalıpları içerip içermediğini belirlemektedir. Bu durum, özellikle doğru bağırsak homeostazisini sağlamak için büyük önem taşımaktadır. ${ }^{28}$ TLR'leri içeren PRR ailesi bu tür kalıpları tanıyan bir molekül sınıfıdır. Bu tür reseptörlerin aktivasyonu, çoğu zaman sitokin ekspresyonunun indüksiyonu ile sonuçlanan akış-aşağı sinyalleme kaskadlarını başlatmaktadır. Bu sitokinler, diğer bağışıklık hücrelerini daha fazla etkilemekte ve buna göre bir bağışıklık tepkisinin seviyesi belirlenmektedir. ${ }^{28}$

Toll benzeri reseptör 2 (TLR2), TLR1 veya TLR6 ile bir heterodimer olarak sinyal iletmekte ve mantarlar ve bakteriler üzerindeki çok çeşitli sinyalleri tanımaktadır. TLR2'nin bir ligand, anti-inflamatuar tepkileri indükleyen Bacteroides fragilis'ten polisakkarit A'dır (PSA) ve TLR2'nin PSA ile uyarılması CD4+ T hücrelerinin plazmasitoid dendritik hücreler tarafından interlökin 10 (IL-10) üretmesini, Treg hücrelerinin klonal çoğalmasını ve indüksiyonunu teşvik etmekte ve bağırsakta Th17 üretimini baskılamaktadır (Şekil 1). ${ }^{29} \mathrm{Bu}$ durumun, inflamasyonun iyileştirilmesine 


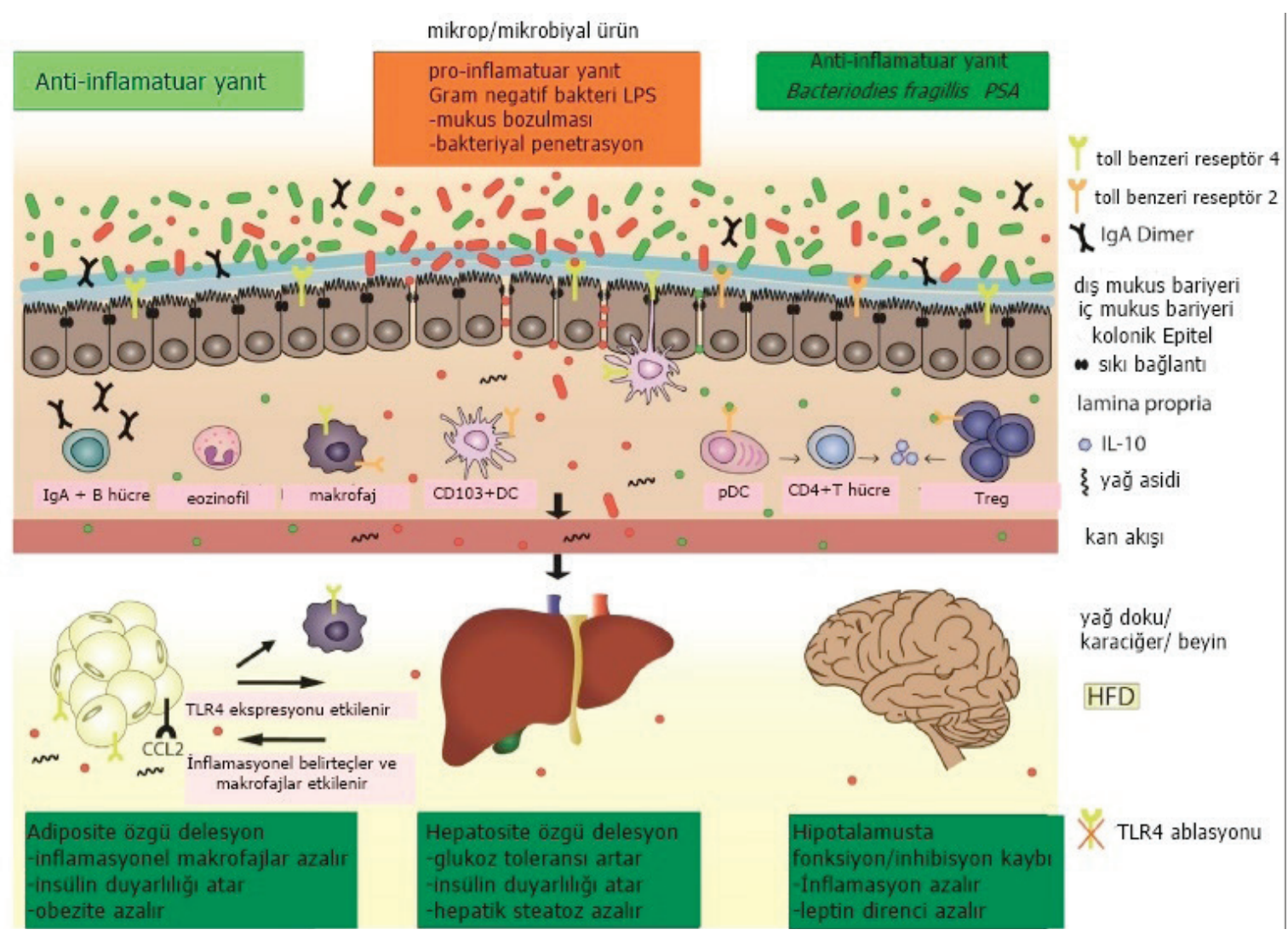

Şekil 1. Mikrobiyal ürünlerin, sistemik bağışıklık ve metabolizmayı etkilemek için bağırsaktaki ve periferdeki toll benzeri reseptörler tarafından algılanma diyagramı Spiljar ve ark., (57)'dan uyarlanmıştır

potansiyel olarak katkıda bulunduğu PSA uygulamasından sonra deneysel otoimmün ensefalomiyelit ve kolit gibi hayvan modellerinde gösterilmiştir. Bu modellerde TLR2 aktivasyonu üzerine anti-inflamatuar yanıt sonrası kommensal bakterilerin "patojenik olmayan" olarak tanındığı gösterilmiştir. Bu durum bize spesifik mikrobiyal türevli mekanizmaların, simbiyotik bakterilere karşı immünolojik toleransı aktif olarak teşvik ettiğini göstermektedir. ${ }^{29,30}$ Bunun aksine Lactobacillus plantarum teikoik asit d-alanilasyonun saptanması üzerine TLR2 sinyallemesinin ayrıca proinflamatuar tepkilere de yol açtığı gösterilmiştir. ${ }^{31}$ Mikroorganizmalar ve bağışıklık hücrelerinin karşılaşma ihtimalleri en yüksek bağırsakta olsa da mikrobiyal ürünlerin sistemik ve metabolik etkileri periferal bölgelerde TLR'ler tarafından tespit edilebilmektedir. TLR2 gen ifadesi, normal yemek diyetine kıyasla yüksek yağlı diyet (HFD) ile beslenen farelerde viseral adipoz dokusunda artmakta, bu da tümör nekroz faktörü alfa (TNF- $\alpha$ ) ekspresyonuna neden olmaktadır ve böylece obezite için tipik olan dokulardaki düşük dereceli bir inflamasyonu desteklemektedir. ${ }^{32}$ $\mathrm{Bu}$ bulgular, TLR2'nin metabolik semptomların proinfl amatuvar bir aracı olması rolünü desteklemektedir.

Toll benzeri reseptör 4 (TLR4), esas olarak gram negatif bakteriyel hücre duvarı bileşeni lipopolisakkariti (LPS) tanımaktadır. Kandaki LPS seviyeleri obezitede veya yüksek kalorili diyet (HCD) ile beslenme sonrası artmakta ve artan Firmicutes/Bacteroidetes oranları ile ilişkili olmaktadır. ${ }^{33}$ TLR4 ekspresyonu, obez veya tip 2 diyabet hastalarının adipoz doku, periferik kan veya kas dokusu örneklerinde ve obez farelerin adipoz dokularında artmakta ve insülin direnci ile ilişkili olmaktadır. ${ }^{34}$ Ayrıca LPS, TLR4 
yoluyla adipoz doku inflamasyonunu indüklemekte ve adipositler üzerinde CCL2 ifadesini arttırmaktadır. Bu kemokin (CCL2), domuz yağı ile beslenen farelerde mikrobiyota kaynaklı makrofaj birikimine ve WAT inflamasyonuna katkıda bulunmaktadır (Şekil 1). ${ }^{35}$ TLR4 fonksiyon kaybı mutasyonu veya TLR4 delesyonu, adipoz dokuya makrofaj infiltrasyonunu azaltmakta, anti-inflamatuar M2 polarizasyonunu teşvik etmekte, doku ve dolaşımdaki inflamatuar belirteç seviyelerini azaltmasına ek olarak tip 1 diyabet için streptozotosin (STZ) ile indüklenen fare modelinde inflamasyonu azaltmaktadır. ${ }^{36}$ IRF3 kaybı, insülin duyarlılığını arttırarak anti-inflamatuar fenotipe aracılık etmekte ve beyaz yağ dokusunun esmerleşmesini arttırmaktadır. ${ }^{37}$ LPS’nin yanı sıra yağ asitleri, adipositler ve makrofajlar dahil olmak üzere çeşitli hücre tiplerinde TLR4 sinyalini arttırabilmekte ve viseral obezite ve insülin direncini indüklemektedir. ${ }^{38}$ Ayrıca adiposit spesifik TLR4 yoksun fareler, TLR4'ün adipoz doku üzerinde iki farklı etkisini göstermektedir. Spesifik olarak bu fareler, HFD ile beslendikten sonra artan tüm vücut ve kas insülin direnci göstermekte, ancak aynı zamanda hiperinsülinemik öglisemik klemp sırasında akut lipit yüklemesinden sonra gelişmiş insülin duyarlılığı da göstermektedir. ${ }^{39}$ Adiposite özgü TLR4 delesyonu ayrıca peritoneal makrofajlarda ve karaciğerde TLR4 ekspresyonunu azalttığı için diğer dokulardaki TLR4 ekspresyonunu da değiștirmektedir. Karaciğerde TLR seviyelerinin değişmesi, önemli sistemik metabolik etkilere neden olmaktadır. Hepatosite özgü TLR4 delesyonu, HFD ile beslenen obez farelerde glikoz toleransı, insülin duyarlılığı ve hepatik steatozu (karaciğer yağlanması) iyileştirmektedir. ${ }^{40}$

Toll benzeri reseptör 5 (TLR5), bakteriyel hareket sisteminin bir bileşeni olan bakteriyel flagellini tanımaktadır. $\mathrm{Bu}$ sinyal yolu, interlökin 1 reseptör antagonist sekresyonunu indükleyerek ve IL- $1 \beta$ ve inflamazom aktivitesini azaltarak bir anti-inflamatuar tepkiye neden olmaktadır. ${ }^{41}$ TLR5 yoksun farelerin ilk olarak, mikrobiyota kompozisyonlarındaki değişikliklerle ilişkili olan insülin direnci ve artan adipozite dahil olmak üzere metabolik sendrom geliştirmeye eğilimli oldukları bildirilmiştir. ${ }^{42}$ Bu fenotip ayrıca epitelyal hücreye özgü TLR5'ten yoksun farelerde de gösterilmiş ve düşük dereceli inflamasyon ile ilişkilendirilmiştir. ${ }^{43}$ Hepatositlerde spesifik TLR5 delesyonu, diyetle indüklenen karaciğer patolojisine yatkınlık kazandırmaktadır. Bu yatkınlığa proinflamatuar sitokinlerin artan ifadesi eşlik etmekte ve Nod benzeri reseptör C4 inflamazomuna bağlı olarak mikrobiyota çeşitliliğinin azalması ile durum düzeltilebilmektedir. ${ }^{44} \mathrm{Bu}$ gözlemler, hepatositlerdeki TLR5'in karaciğerin korunmasında ve diyetle indüklenen karaciğer hastalığının önlenmesinde rol oynadığını göstermektedir.

\section{Bağırsak Mikrobiyotası ve TLR Yolu Arasındaki İlişkinin Klinik Anlamı}

Bağışıklık ve metabolizma arasındaki enerjinin yer değiştirmesi kavramı, besin veya enerji kıtlı̆̆ durumuna dayanmaktadır. Ancak günümüzde yaşanan güncel sorun, aşırı beslenmeden kaynaklanan kronik tıbbi problemlerdir. Obezite sıklıkla, lokal ve sistemik inflamasyonu uyaran ve sonunda metabolik disfonksiyonu ve kardiyovasküler riskleri ağırlaştıran bir hastalıktır. ${ }^{45,46}$ Sonuç olarak, inflamasyonun kontrol edilmesi, obezite ile ilişkili hastalıklar için terapötik bir seçenek olarak görülmektedir. Bununla birlikte, anti-inflamatuar ilaç kullanımı, kardiyovasküler hastalık riskini de arttırabilmektedir. ${ }^{46}$ Ek olarak, TLR-yoksun hayvan modellerinde metabolik fonksiyonlar üzerinde gözlenen tutarlı ve faydalı etkilere rağmen, mevcut insan verilerinden TLR polimorfizmi ile metabolik hastalıklar arasında kesin bir ilişki gösterilememiştir. ${ }^{47,48}$ Akut miyokard enfarktüs geçirmemiş, koroner anjiyografi ile 1894 hastanın incelendiği bir çalışmada, doğal tip allele kıyasla TLR4 (Asp299Gly) varyant alleli olanlarda diyabet prevalansının \%7 daha düşük olduğu bildirilmiştir. ${ }^{48}$ Buna karşılık, 2000'de 722 denekten oluşan bir alt popülasyonunun incelendiği bir başka çalışmada, heterozigot ve homozigot TLR4 varyant alelleri ile tip 2 diyabet, bozulmuş glukoz toleransı veya metabolik sendromun diğer bileşenleri ile hiçbir ilişki bulunamadığı belirtilmiştir. ${ }^{49}$ Öte yandan ilişkisiz bir TLR5 polimorfizminin kilo alımını önlediği ancak 
diyabet için riski arttırdığı belirtilmiştir. ${ }^{50}$ TLR2 polimorfizminin (rs3804100, 1350 T / C) tip 1 diyabetle ilişkisini inceleyen iki çalışma çelişkili sonuçlar ortaya koymuştur. ${ }^{51}$ Bağırsak mikrobiyotası üzerindeki bu bireysel farklılıkların nedenlerinin, coğrafi, sosyo ekonomik veya epigenetik etkiler olabileceğini düşündürmektedir. Benzer şekilde, bağırsak mikrobiyotasındaki değişikliğin obeziteye ve metabolik işlev bozukluğuna katkıda bulunabileceği belirtilmiş olsa da farklı laboratuvarlardan alınan sonuçların biribirini desteklememediği görülmektedir. Bağırsak mikrobiyotasının evrimsel gelişiminin, konakçıda enerjiyi arttırmak ile ilgili olduğu belirtilmektedir ve antibiyotik kullanımı ile mikrobiyotanın ortadan kaldırılması durumunda beyaz yağ dokunun kahverengi yağ dokusuna dönmeye başladığı ve obeziteye karşı koruyucu olduğu belirtilmektedir. ${ }^{52}$ Son yıllarda kilo artışı sağlamak amacıyla hayvancılıkta antibiyotik kullanımı yaygınlıkla artmıştır. ${ }^{53}$ Yaşamın erken dönemlerinde antibiyotik kullanımı çocukluk çağı obezitesi ile ilişkilendirilmektedir. Ayrıca, aynı cinse ait Lactobacillus'lar içinde; Lactobacillus plantarum kilo kaybını arttırurken, Lactobacillus ingluiviei ve Lactobacillus acidophilus kilo alımını arttırmaktadır. ${ }^{54}$ Vücut ağırlığı ve metabolizmayı düzenlemek için bağırsak mikrobiyotasının manipüle edilmesi, konakçı ve bağırsak mikrobiyotası arasındaki karmaşık ilişkinin daha ayrıntılı araştırmasının gerekliliğini ortaya koymaktadır. Bağırsak mikrobiyotası diyetle şekillendirilebilmektedir ve etoburlarda, omnivorlarda ve otoburlar arasında önemli farklılıklar gözlenmektedir. ${ }^{55}$ Yüksek yağlı diyetin neden olduğu düşük dereceli sistemik iltihaplanma, özellikle çapraz enfeksiyonun yüksek oranda mümkün olduğu hayvan yağlarının sindirilmesinden kaynaklanan gıda kaynaklı patojenlere karşı evrimsel bir koruyucu mekanizma olabilmektedir.

Modern tıpta, TLR antagonistleri, immünosupresyonun sağladığı faydalı etkiler nedeniyle metabolik ve kardiyovasküler hastalıklar için araştırılmıştır. ${ }^{56,57}$ Bununla birlikte, bu kronik hastalıklarda bağırsak mikrobiyotasından türetilen moleküller TLR'leri aktive edebilirse, konakçıdaki katabolizma ortaya konabilecektir. Böyle bir senaryo- da TLR yolağının engellenmesi, enerji depolamayı teşvik edecektir; bununla birlikte, bakteri ürünlerinin çeşitliliği ve TLR'lerin farklı organ ve hücre tiplerindeki ifadesi dikkate alındığında, belirli bir yerde metabolik disfonksiyonu şiddetlendirici istenmeyen anabolik olaylar ortaya çıkabilecektir. Aynı zamanda bir diğer tıbbi sorun olarak enfeksiyona karşı savunmasızlığı arttırdığı için konakçının TLR aktivitesini bastırması söz konusu olabilmektedir. TLR yolunun işlevleri ve TLR’ler ile bağırsak mikrobiyotası arasındaki etkileşim üzerine kapsamlı bir araştırma, kronik hastalıklarda TLR'lerin agonizm/antagonizminin klinik uygulamasının daha iyi değerlendirmesini sağlayacaktır. ${ }^{58}$

\section{SONUÇ}

İnce bağırsak, sürekli olarak diyet ve mikrobiyal antijenlere maruz kalan geniş bir yüzey alanına sahiptir. Bu antijenlerin, homeostazı sürdürmek için bağışıklık sistemi tarafından tolere edilmesi gerekmektedir. Bu önemli rol, TLR'ler gibi bağışıklık sensörleri tarafından gerçekleştirilmekte ve bazı durumlarda doğuştan gelen bağışıklık sisteminin konağı korumada başarısız olmasına ek olarak kronik iltihaplanma ve diğer bozukluklar ortaya çıkabilmektedir. Çevre, genetik ve konakçı bağışıklığının, bağırsak mukozasında TLR işlevini kontrol eden çok boyutlu ve oldukça etkileşimli bir düzenleyici üçlü oluşturmaktadır. Bu üçlü içinde dengenin bozulması, akut ve kronik bağırsak iltihaplanma süreçlerine kritik olarak katkıda bulunan anormal TLR sinyalini teşvik edebilmektedir. Genetik ve çevre etkisiyle bağırsak mikrobiyotasındaki değişiklikler, sorunlu konak bağışıklık tepkisine neden olabilmektedir Mikrobiyota manipülasyonları ile hastalarda mikrobiyotanın yeniden programlanması erişilebilir ve ümit verici tedavi şekilleri sunabilir (anti-obezite tedavisi gibi). Bu nedenle, mikrobiyota ve bağışıklık sistemi arasındaki karmaşık ve karşılıklı etkileşimi ve bu ilişkinin metabolik parametreleri nasıl düzenleyeceğini anlamak, metabolik hastalıkların tedavisinde ilerlemeler sağlayabilecektir.

\section{Açıklamalar}


J Biotechnol and Strategic Health Res. 2021;5(1):12-21

DURGUN, ÖZKAN, Bağırsak Mikrobiyotası ve Toll Benzeri Reseptörler Arasındaki İlişki

Çalışmayı maddi olarak destekleyen kişi/kuruluş yoktur ve

yazarların herhangi bir çıkar dayalı ilişkisi yoktur. 
J Biotechnol and Strategic Health Res. 2021;5(1):12-21

Kaynaklar

1. Hooper LV, Gordon JI. Commensal host-bacterial relationships in the gut. Science. 2001;292(5519):1115-1118. doi:10.1126/science.1058709

2. Guarner F, Malagelada JR. Gut flora in health and disease. Lancet. 2003;361(9356):512519. doi:10.1016/S0140-6736(03)12489-0

3. Hooper LV, Macpherson AJ. Immune adaptations that maintain homeostasis with the intestinal microbiota. Nat Rev Immunol. 2010;10(3):159-169. doi:10.1038/nri2710

4. Johansson ME, Larsson JM, Hansson GC. The two mucus layers of colon are organized by the MUC2 mucin, whereas the outer layer is a legislator of host-microbial interactions. Proc Natl Acad Sci U S A. 2011;108 Suppl 1(Suppl 1):4659-4665. doi:10.1073/ pnas. 1006451107

5. Benckert J, Schmolka N, Kreschel C, et al. The majority of intestinal IgA+ and IgG+ plasmablasts in the human gut are antigen-specific. J Clin Invest. 2011;121(5):1946-1955. doi:10.1172/JCI44447

6. Güçlü Durgun S., Determination of gut microbiota fingerprints of healthy families using by culturomics maldi-TOF MS approach, Yüksek lisans tezi, 2019

7. Sartor RB. Microbial influences in inflammatory bowel diseases. Gastroenterology. 2008;134(2):577-594. doi:10.1053/j.gastro.2007.11.059

8. Deveci Ozkan A, Kaleli S, Onen HI, et al. Anti-inflammatory effects of nobiletin on TLR4/TRIF/IRF3 and TLR9/IRF7 signaling pathways in prostate cancer cells. Immunopharmacol Immunotoxicol. 2020;42(2):93-100. doi:10.1080/08923973.2020.1725040

9. Chassaing B, Ley RE, Gewirtz AT. Intestinal epithelial cell toll-like receptor 5 regulates the intestinal microbiota to prevent low-grade inflammation and metabolic syndrome in mice. Gastroenterology. 2014;147(6):1363-77.e17. doi:10.1053/j.gastro.2014.08.033

10. Brenner C, Galluzzi L, Kepp O, Kroemer G. Decoding cell death signals in liver inflammation. J Hepatol. 2013;59(3):583-594. doi:10.1016/j.jhep.2013.03.033

11. Feingold KR, Moser A, Shigenaga JK, Grunfeld C. Inflammation inhibits the expression of phosphoenolpyruvate carboxykinase in liver and adipose tissue. Innate Immun. 2012;18(2):231-240. doi:10.1177/1753425911398678

12. Cullender TC, Chassaing B, Janzon A, et al. Innate and adaptive immunity interact to quench microbiome flagellar motility in the gut. Cell Host Microbe. 2013;14(5):571-581. doi:10.1016/j.chom.2013.10.009

13. Carvalho FA, Aitken JD, Vijay-Kumar M, Gewirtz AT. Toll-like receptor-gut microbiota interactions: perturb at your own risk!. Annu Rev Physiol. 2012;74:177-198. doi:10.1146/ annurev-physiol-020911-153330

14. Rock FL, Hardiman G, Timans JC, Kastelein RA, Bazan JF. A family of human receptors structurally related to Drosophila Toll. Proc Natl Acad Sci U S A. 1998;95(2):588-593. doi:10.1073/pnas.95.2.588

15. Kobe B, Deisenhofer J. A structural basis of the interactions between leucine-rich repeats and protein ligands. Nature. 1995;374(6518):183-186. doi:10.1038/374183a0

16. Kobe B, Deisenhofer J. A structural basis of the interactions between leucine-rich repeats and protein ligands. Nature. 1995;374(6518):183-186. doi:10.1038/374183a0

17. Krawczyk CM, Holowka T, Sun J, et al. Toll-like receptor-induced changes in glycolytic metabolism regulate dendritic cell activation. Blood. 2010;115(23):4742-4749. doi:10.1182/blood-2009-10-249540

18. Everts B, Amiel E, Huang SC, et al. TLR-driven early glycolytic reprogramming via the kinases TBK1-IKK囚 supports the anabolic demands of dendritic cell activation. Nat Immunol. 2014;15(4):323-332. doi:10.1038/ni.2833

19. Rodríguez-Prados JC, Través PG, Cuenca J, et al. Substrate fate in activated macrophages: a comparison between innate, classic, and alternative activation. J Immunol. 2010;185(1):605-614. doi:10.4049/jimmunol.0901698

20. Sanin DE, Prendergast CT, Mountford AP. IL-10 Production in Macrophages Is Regulated by a TLR-Driven CREB-Mediated Mechanism That Is Linked to Genes Involved in Cell Metabolism. J Immunol. 2015;195(3):1218-1232. doi:10.4049/jimmunol.1500146

21. Castrillo A, Joseph SB, Vaidya SA, et al. Crosstalk between LXR and toll-like receptor signaling mediates bacterial and viral antagonism of cholesterol metabolism. Mol Cell. 2003;12(4):805-816. doi:10.1016/s1097-2765(03)00384-8

22. Chow EK, Castrillo A, Shahangian A, et al. A role for IRF3-dependent RXRalpha repression in hepatotoxicity associated with viral infections. J Exp Med. 2006;203(12):25892602. doi:10.1084/jem.20060929

23. Vaz B, de Lera ÁR. Advances in drug design with RXR modulators. Expert Opin Drug Discov. 2012;7(11):1003-1016. doi:10.1517/17460441.2012.722992

24. Li Q, Pène V, Krishnamurthy S, Cha H, Liang TJ. Hepatitis C virus infection activates an innate pathway involving IKK- $\alpha$ in lipogenesis and viral assembly. Nat Med. 2013;19(6):722-729. doi:10.1038/nm.3190

25. Isogawa M, Robek MD, Furuichi Y, Chisari FV. Toll-like receptor signaling inhibits hepatitis B virus replication in vivo. J Virol. 2005;79(11):7269-7272. doi:10.1128/ JVI.79.11.7269-7272.2005

26. Huang YL, Morales-Rosado J, Ray J, et al. Toll-like receptor agonists promote prolonged triglyceride storage in macrophages. J Biol Chem. 2014;289(5):3001-3012. doi:10.1074/ jbc.M113.524587

27. Xu X, Grijalva A, Skowronski A, van Eijk M, Serlie MJ, Ferrante AW Jr. Obesity activates a program of lysosomal-dependent lipid metabolism in adipose tissue macrophages independently of classic activation. Cell Metab. 2013;18(6):816-830. doi:10.1016/j. cmet.2013.11.001

28. Rakoff-Nahoum S, Paglino J, Eslami-Varzaneh F, Edberg S, Medzhitov R. Recognition of commensal microflora by toll-like receptors is required for intestinal homeostasis. Cell. 2004;118(2):229-241. doi:10.1016/j.cell.2004.07.002

29. Dasgupta S, Erturk-Hasdemir D, Ochoa-Reparaz J, Reinecker HC, Kasper DL. Plasmacytoid dendritic cells mediate anti-inflammatory responses to a gut commensal molecule via both innate and adaptive mechanisms. Cell Host Microbe. 2014;15(4):413-423. doi:10.1016/j.chom.2014.03.006

30. Ochoa-Repáraz J, Mielcarz DW, Wang Y, et al. A polysaccharide from the human com mensal Bacteroides fragilis protects against CNS demyelinating disease. Mucosal Immunol. 2010;3(5):487-495. doi:10.1038/mi.2010.29

31. Smelt MJ, de Haan BJ, Bron PA, et al. The impact of Lactobacillus plantarum WCFS1 teichoic acid D-alanylation on the generation of effector and regulatory T-cells in healthy mice. PLoS One. 2013;8(4):e63099. Published 2013 Apr 30. doi:10.1371/journal. pone.0063099

32. Murakami K, Bujo H, Unoki H, Saito Y. High fat intake induces a population of adipocytes to co-express TLR2 and TNFalpha in mice with insulin resistance. Biochem Biophys Res Commun. 2007;354(3):727-734. doi:10.1016/j.bbrc.2007.01.039

33. Cani PD, Neyrinck AM, Fava F, et al. Selective increases of bifidobacteria in gut microflora improve high-fat-diet-induced diabetes in mice through a mechanism associated with endotoxaemia. Diabetologia. 2007;50(11):2374-2383. doi:10.1007/s00125-007-0791-0

34. Shapiro H, Singer P, Attal-Singer J. Comment on: Reyna et al. (2008) Elevated toll-like receptor 4 expression and signaling in muscle from insulin-resistant subjects. Diabetes 57:2595-2602. Diabetes. 2009;58(4):e5-e7. doi:10.2337/db09-0022

35. Caesar R, Tremaroli V, Kovatcheva-Datchary P, Cani PD, Bäckhed F. Crosstalk between Gut Microbiota and Dietary Lipids Aggravates WAT Inflammation through TLR Signaling. Cell Metab. 2015;22(4):658-668. doi:10.1016/j.cmet.2015.07.026

36. Devaraj S, Tobias P, Jialal I. Knockout of toll-like receptor-4 attenuates the pro-inflammatory state of diabetes [published correction appears in Cytokine. 2011 Dec;56(3):832]. Cytokine. 2011;55(3):441-445. doi:10.1016/j.cyto.2011.03.023

37. Kumari M, Wang X, Lantier L, et al. IRF3 promotes adipose inflammation and insulin resistance and represses browning. J Clin Invest. 2016;126(8):2839-2854. doi:10.1172/ JCI86080

38. Shi H, Kokoeva MV, Inouye K, Tzameli I, Yin H, Flier JS. TLR4 links innate immunity and fatty acid-induced insulin resistance. J Clin Invest. 2006;116(11):3015-3025. doi:10.1172/JCI28898

39. Tao C, Holland WL, Wang QA, et al. Short-Term Versus Long-Term Effects of Adipocyte Toll-Like Receptor 4 Activation on Insulin Resistance in Male Mice. Endocrinology. 2017;158(5):1260-1270. doi:10.1210/en.2017-00024

40. Jia L, Vianna CR, Fukuda M, et al. Hepatocyte Toll-like receptor 4 regulates obesity-induced inflammation and insulin resistance. Nat Commun. 2014;5:3878. Published 2014 May 12. doi:10.1038/ncomms 4878

41. Carvalho FA, Aitken JD, Gewirtz AT, Vijay-Kumar M. TLR5 activation induces secretory interleukin-1 receptor antagonist (sIL-1Ra) and reduces inflammasome-associated tissue damage. Mucosal Immunol. 2011;4(1):102-111. doi:10.1038/mi.2010.57

42. Vijay-Kumar M, Aitken JD, Carvalho FA, et al. Metabolic syndrome and altered gut microbiota in mice lacking Toll-like receptor 5. Science. 2010;328(5975):228-231. doi:10.1126/science. 1179721

43. Chassaing B, Ley RE, Gewirtz AT. Intestinal epithelial cell toll-like receptor 5 regulates the intestinal microbiota to prevent low-grade inflammation and metabolic syndrome in mice. Gastroenterology. 2014;147(6):1363-77.e17. doi:10.1053/j.gastro.2014.08.033

44. Etienne-Mesmin L, Vijay-Kumar M, Gewirtz AT, Chassaing B. Hepatocyte Toll-Like Receptor 5 Promotes Bacterial Clearance and Protects Mice Against High-Fat Diet-Induced Liver Disease. Cell Mol Gastroenterol Hepatol. 2016;2(5):584-604. Published 2016 May 5. doi:10.1016/j.jcmgh.2016.04.007

45. DiAngelo JR, Bland ML, Bambina S, Cherry S, Birnbaum MJ. The immune response attenuates growth and nutrient storage in Drosophila by reducing insulin signaling. Proc Natl 
J Biotechnol and Strategic Health Res. 2021;5(1):12-21

Acad Sci U S A. 2009;106(49):20853-20858. doi:10.1073/pnas.0906749106

46. Coxib and traditional NSAID Trialists' (CNT) Collaboration, Bhala N, Emberson J, et al. Vascular and upper gastrointestinal effects of non-steroidal anti-inflammatory drugs: meta-analyses of individual participant data from randomised trials. Lancet. 2013;382(9894):769-779. doi:10.1016/S0140-6736(13)60900-9

47. Illig T, Bongardt F, Schöpfer A, et al. The endotoxin receptor TLR4 polymorphism is not associated with diabetes or components of the metabolic syndrome. Diabetes. 2003;52(11):2861-2864. doi:10.2337/diabetes.52.11.2861

48. Kolek MJ, Carlquist JF, Muhlestein JB, et al. Toll-like receptor 4 gene Asp299Gly polymorphism is associated with reductions in vascular inflammation, angiographic coronary artery disease, and clinical diabetes. Am Heart J. 2004;148(6):1034-1040. doi:10.1016/j. ahj.2004.05.049

49. Santin I, Bilbao JR, de Nanclares GP, Calvo B, Castaño L. No association of TLR2 and TLR4 polymorphisms with type I diabetes mellitus in the Basque population. Ann N Y Acad Sci. 2006;1079:268-272. doi:10.1196/annals.1375.040

50. Al-Daghri NM, Clerici M, Al-Attas O, et al. A nonsense polymorphism (R392X) in TLR5 protects from obesity but predisposes to diabetes. J Immunol. 2013;190(7):3716-3720. doi:10.4049/jimmunol.1202936

51. Dasu MR, Devaraj S, Park S, Jialal I. Increased toll-like receptor (TLR) activation and TLR ligands in recently diagnosed type 2 diabetic subjects. Diabetes Care. 2010;33(4):861-868. doi:10.2337/dc09-1799

52. Suárez-Zamorano N, Fabbiano S, Chevalier C, et al. Microbiota depletion promotes browning of white adipose tissue and reduces obesity. Nat Med. 2015;21(12):1497-1501. doi:10.1038/nm.3994

53. Dibner JJ, Richards JD. Antibiotic growth promoters in agriculture: history and mode of action. Poult Sci. 2005;84(4):634-643. doi:10.1093/ps/84.4.634

54. Angelakis E, Merhej V, Raoult D. Related actions of probiotics and antibiotics on gut microbiota and weight modification. Lancet Infect Dis. 2013;13(10):889-899. doi:10.1016/ S1473-3099(13)70179-8

55. Ley RE, Hamady M, Lozupone C, et al. Evolution of mammals and their gut microbes [published correction appears in Science. 2008 Nov 21;322(5905):1188]. Science. 2008;320(5883):1647-1651. doi:10.1126/science.1155725

56. Frosali S, Pagliari D, Gambassi G, Landolfi R, Pandolfi F, Cianci R. How the Intricate Interaction among Toll-Like Receptors, Microbiota, and Intestinal Immunity Can Influence Gastrointestinal Pathology. J Immunol Res. 2015;2015:489821. doi:10.1155/2015/489821

57. Spiljar M, Merkler D, Trajkovski M. The Immune System Bridges the Gut Microbiota with Systemic Energy Homeostasis: Focus on TLRs, Mucosal Barrier, and SCFAs. Front Immunol. 2017;8:1353. Published 2017 Oct 30. doi:10.3389/fimmu.2017.01353 